УДК 324:004+328.32+321.7(477)

https://doi.org/10.34142/24130060.2019.17.1.06

\title{
ЕЛЕКТРОННЕ ГОЛОСУВАННЯ: МОЖЛИВОСТІ УКРАЇНСЬКОЇ РЕЦЕПЦІї
}

\author{
Ю.А. Данько, Н.Г. Білоцерківська
}

Харківський національний педагогічний університет імені Г.С. Сковороди

У статті розглянуто переваги та недоліки впровадження та застосування системи електронного голосування у різних країнах світу та перспективи впровадження електронного голосування в Україні. Зазначено, щзо е-демократія стає безпосереднім інструментом демократизації і розвитку суспільства в інформаиійному напрямку. Одним 3 механізмів е-демократії $\epsilon$ електронне голосування. Електронне голосування визначається як прочедура здійснення волевиявлення з використанням електронних засобів та як автоматизований прочес підрахунку голосів. Також автором розглянуто форми е-голосування, які застосовуються у світовій практииі. Проаналізовано досвід використання системи е-голосування у різних країнах світу. Автор також розглядає заходи які розробляє Украӥна для впровадження системи е-голосування. Спираючись на досвід інших краӥн визначено, що електронне голосування треба використовувати паралельно з традииійним волевиявленням.

Ключові слова: інформачійне суспільство, демократія, вибори, виборчий прочес, електронна демократія, електронний уряд, електронне голосування, електронні вибори.

\section{ЭЛЕКТРОННОЕ ГОЛОСОВАНИЕ: ВОЗМОЖНОСТИ УКРАИНСКОЙ РЕЦЕПЦИИ}

\section{Ю.А. Данько, Н.Г. Белоцерковская}

В статье рассмотрень преимущества и недостатки внедрения и применения системы электронного голосования в разных странах мира и перспективы внедрения электронного голосования в Украине. Отмечено, что е-демократия становится непосредственным инструментом демократизации и развития общества в информационном направлении. Одним из механизмов электронной демократии выступает электронное голосование. Электронное голосование определяется как прочедура осуществления волеизъявления с использованием электронных средств и как автоматизированный прочесс подсчета голосов. Также автором рассмотрены формы еголосования, которые применяются в мировой практике. Проанализирован опыт использования системы электронной голосования в разных странах мира. Автор также рассматривает меры разрабатываемые Украиной для внедрения системы электронной голосования. Опираясь на опыт других стран определено, что электронное голосование надо использовать параллельно с традиционным волеизъявлением.

Ключевые слова: информачионное общество, демократия, выборы, избирательньй процесс, электронная демократия, электронное правительство, электронное голосование, электронные выборы. 


\section{ELECTRONIC VOTING: OPPORTUNITIES OF UKRAINIAN RECEPTION}

\section{Y. Danko, N. Bilotserkivska}

The article considers the advantages and disadvantages of implementing and applying the electronic voting system in different countries of the world and the prospects for the introduction of electronic voting in Ukraine. It is noted that e-democracy is a direct tool of democratization and development of the society in the information direction. One of the mechanisms of e-democracy is e-voting. Electronic voting is considered as a procedure for the implementation of the expression of will with the use of electronic means and as an automated process of counting votes, which simplifies the voting procedure and contributes to raising the level of electoral activity. It has been determined that e-voting, although it is one of the most complex forms of e-democracy, can still increase the interest of citizens, namely, the young people in the political life of the country, reduce the cost of the election process, enable citizens with disabilities to carry out a process of expression of will, improve the reliability of the procedure for counting election results. The author also examines the forms of e-voting that are used in world practice, namely: voting through the Internet, voting in the booth using "electronic ballot boxes" and e-voting with the help of a mobile phone. The experience of using e-voting system in different countries of the world, such as USA, Brazil, Estonia, Austria, Finland, Switzerland, France, Great Britain, the Netherlands, Germany, Norway, etc., is analyzed. Identified problems faced by countries in elections when using the e-voting system. The author also considers the measures that Ukraine is developing to implement the e-voting system. In particular, it was noted that the first attempts to establish on the legislative level the introduction of electronic voting in Ukraine were recorded as early as 2011. At present, the use of electronic voting in Ukraine is only in the stage of active discussion. Based on the experience of other countries, it has been determined that electronic voting should be used in parallel with the traditional expression of will.

Key words: information society, democracy, elections, electoral process, e-democracy, egovernment, e-voting, electronic elections.

Постановка проблеми. Вибори є однією 3 ключових форм прояву демократії у країні. Вони є найвищим реальним вираження волі народу, конституційним спосіб формування органів державної влади та органів місцевого самоврядування на основі вільного волевиявлення громадян (Готун, 2008, с. 51).

В епоху інформаційного суспільства, коли збільшується обсяг інформації та знань в житті суспільства, відповідно зростає роль інформаційних технологій в суспільних та політико-правових відносинах. Застосування нових інформаційно-комунікаційних технологій змінює політичне життя, суспільний дискурс та інструменти мобілізації громадян багатьох країн світу. Вираження волі громадян через вибори $\epsilon$ найважливішим елементом демократичної системи державного управління, 
що формує представницькі органи державної влади та місцевого самоврядування (Константинівська, 2018, с. 162). Як показала практика виборчих кампаній кінця XX століття політична активність громадян та їх зацікавленість у формуванні представницьких органів влади значно знизилась, тому демократичні зарубіжні країни почали задумуватися про провадження нових способів та форм голосування.

Держава, яка не тільки декларує демократичні ідеали, а і прагне їх втілення у життя, має створювати належні умови для волевиявлення громадян. Одне з центральних місць серед цих умов посідає доступність процедури голосування. Формування виборчого законодавства країни має проходити з урахуванням особливостей соціального розвитку країни, рівня політичної культури населення, розвитку технічних засобів та рівня їх доступності. Враховуючи небезпеки руйнування принципів прозорості та маніпуляції 3 результатами голосування були запроваджені системи голосування 3 дистанційним доступом або ж такі, що спрощують процедуру голосування i в такий спосіб сприяють підвищенню рівня виборчої активності (Фоміна, 2014, с. 112).

Сьогодні дослідники визнають, що електронне голосування, хоча $є$ однією з найскладніших форм електронної демократії, все ж може підвищити інтерес громадян, а саме молоді до політичного життя країни, зменшити витрати на виборчий процес, збільшити доступ громадян 3 обмеженими фізичними можливостями до процедури голосування, покращити надійність процедури підрахунку результатів виборів (Константинівська, 2018, с. 162).

Аналіз актуальних досліджень. Розгляд проблем електронної демократії представлено роботами Е. Брека, К. Вергеса, Д. Кедді, Ф. Нобла та роботами вітчизняних дослідників А. Акімова, А. Семенченка, С. Дзюби, І. Жиляєва, Х. Кохалик, Н. Махначової, С. Полумієнка, І. Рубана та ін.

Питання запровадження системи електронного голосування та підходи до його організації досліджували такі зарубіжні та вітчизняні науковці, як М. Бучин, М. Грачов, Н. Грицяк, Р. Кріммер, А. Константинівська, К. Матреніна, 

М. Міхровська, М. Мостова,
А. Насибулін,
С. Овчинніков,
О. Пєскова,
В. Пітере, І. Половко, А. Проссер, І. Сіденко, С. Соловйов, Н. Титовська, Р. Шустер, Д. Угрюмов, С. Фатєєва, В. Хализєв.

Мета статті - аналіз переваг та недоліків впровадження системи електронного голосування у різних країнах світу та перспектив впровадження електронного голосування в Україні.

Виклад основного матеріалу. Початок XXI століття відзначився періодом інтенсивних трансформацій, які позначилися бурхливим розвитком цифрових технологій. Технологічні зміни охопили усі сфери життя суспільства, не виключенням $є$ і функціонування держави та їі відносини 3 громадянами, що проявилося у вигляді впровадження електронної демократії (Махначова, 2018).

Активне впровадження інформаційних технологій до системи суспільно-політичних відносин розширює можливості громадян щодо їх громадської участі, створює умови для формування якісно нового рівня активності та участі громадян, які користуються сучасними технологіями не лише в особистих інтересах, а й $з$ метою суспільно-політичної участі в публічному управлінні. Електронна участь громадян в управлінні змінює сутність суспільних комунікацій, формуючи нову систему взаємодії громадян з владою - систему електронної демократії («е-демократії») (Малиновський, Грицяк та Семенченко, 2017, с. 40).

Електронна демократія стає безпосереднім інструментом демократизації і розвитку суспільства в інформаційному напрямку. Концепт «е-демократії», який уперше з'явився у США, не має однозначного тлумачення. Його інтерпретують у вузькому й у широкому значенні. У широкому значенні під «е-демократією» розуміється залучення громадян, через використання інформаційних технологій, до участі у вирішенні різноманітних суспільно-політичних питань як шляхом вільного обговорення, так і участі у виборах, референдумах тощо. У вузькому значенні розглядається лише технологічний аспект, тобто, під цим терміном 
розуміється використання інформаційних технологій для забезпечення (електронного супроводу) прав громадян. (Малиновський, Грицяк та Семенченко, 2017, с. 41-42).

Можливості застосування нових технологій простягаються від інформування про різних претендентів на виборні посади й діяльність партій, участь в електронному голосуванні (е-голосуванні) електронних виборах (е-виборах). Такі і інші форми електронної демократії широко вводяться i використовуються в найбільш демократично розвинених країнах (Акімов, 2018, c. 24).

Отже одним 3 механізмів е-демократії $є$ електронне голосування, яке сьогодні викликає жвавий інтерес як у дослідників виборчих технологій, так і у політологів.

Електронне голосування термін, що використовується для характеристики різних типів голосування, та охоплює як процес здійснення голосування за допомогою електронних засобів, так і процес автоматичного підрахунку голосів за допомогою електронних пристроїв та спеціального програмного забезпечення (Шелудько, 2015, с. 77).

Електронне голосування згідно «Концепції розвитку електронної демократії в Україні» розуміється як голосування з будь-якого публічного питання, участь в опитуваннях, виборах, референдумах, що передбачає використання електронних засобів для ідентифікації та підрахунку голосів (Законодавство України, 2017).

3 огляду на викладене, електронне голосування є формою електронної демократії, яка становить процедуру здійснення волевиявлення 3 використанням інформаційно-комунікаційних технологій чи обладнання; автоматизований процес підрахунку голосів у цифровому форматі. Це поняття може застосовуватися як в аспекті вираження волевиявлення під час виборів, так і при участі в референдумі (Барікова, 2016, с. 12).

На сьогоднішній день у світі існують такі форми електронного голосування: 
- голосування за допомогою Інтернету (виборцями використовується персональний комп’ютер з підключенням до Інтернету, який приймає голос виборця і передає його на зберігання в інший, віддалений комп'ютер);

- голосування в кабінці за допомогою «електронних виборчих скриньок» (інтерфейсом такої системи може бути сенсорний екран або сканер, який зчитує позначку, поставлену виборцем у виборчому бюлетені. Далі голос реєструється і зберігається в самому пристрої для е-голосування). Тобто громадяни голосують на своїй традиційній виборчій дільниці тільки із застосуванням інформаційних технологій;

- голосування за допомогою мобільного телефону (Шелудько, 2015, c. 77; ACE project, 2019).

Вперше експеримент 3 голосуванням через мережу Інтернет було здійснено в 2000 році у штаті Орегон, США. 3 часом технології голосування вдосконалювалися. Комплекси для електронного голосування широко застосовувалися на місцевих і федеральних виборах США. У 2002 році був прийнятий федеральний Закон «Help America Vote Act» (Допоможемо Америці проголосувати). Метою якого була відмова від паперових бюлетенів, важільних апаратів (виборці тиснуть на важіль біля прізвища кандидата) та перфокарткових машин (на спеціальних картах поряд 3 прізвищами кандидатів пробиваються отвори) (Начос, 2018, с. 59).

В США було визнано однією 3 найбільш перспективних електронну систему безпосереднього запису, яка посіла друге місце по застосуванню на виборах 2004 року. В ній не застосовувалося ніяких паперових бюлетенів: виборці здійснювали голосування за допомогою пристроїв 3 сенсорним екраном або спеціального кнопкового пристрою, які заносили дані до пам'яті комп’ютера.

Проте найбільшого поширення у виборчій кампанії 2004 року набула система сканування бюлетенів, коли за допомогою спеціального пристрою або вручну виборець заповнював бюлетень, який потім зчитувався сканером на машині для голосування. Це дало змогу автоматизувати процес 
підрахунку голосів на виборчих дільницях та уникнути можливих проблем 3 фальсифікацією бюлетенів під час підрахунку голосів (Готун, 2008, с. 51).

Сьогодні застосування «електронних виборчих скриньок» залишається найпоширенішою формою електронного голосування. Цей тип голосування користується популярністю тому, що «електронні виборчі скриньки» можуть працювати автономно, без підключення до енергомереж та комунікацій, що особливо актуально в країнах, де виборчі дільниці розташовані в малонаселеній місцевості або на територіях 3 обмеженим доступом до телефонних ліній і відсутністю мережі Інтернет (Барікова, 2016, с. 17).

Ця система електронного голосування вперше була впроваджена у Бразилії. В 1996 р. система була успішно апробована на муніципальних виборах у 57 містах, вже до 2000 р. система була застосована на виборах муніципалітетів на всій території країни, а у 2002 р. цей досвід застосували на перших у світі електронних загальнонаціональних виборах глави держави. За ходом виборів спостерігали як представники різних країн світу (США, Японії, Мексики, Венесуели) так і представники міжнародної організації «Transparency International», які підтвердили, що процедура голосування виключала можливості підтасувань і зловживань під час волевиявлення (Готун, 2008, с. 52).

Безумовним лідером у сфері впровадження електронного голосування $\epsilon$ Естонія. 3 моменту запровадження Інтернет-голосування у 2005 р. на місцевих виборах, такий метод голосування застосовувався тут 7 разів: у жовтні 2005, 2009 та 2013 рр. на місцевих виборах, у 2007 та 2011 рр. на парламентських виборах та у 2009 та 2014 рр. на виборах до Європейського Парламенту. Кількість виборців які голосували он-лайн також 3 роками зростала від 2\% у 2005 р. до $31 \%$ у 2014 р. (Начос, 2018, с. 60; Готун, 2008, с. 52), незважаючи на масові хакерські атаки, які під час виборів 2007 р. ледь не підірвали довіру громадян країни до е-голосування (Кохалик, 2015, с. 171).

В 2009 році у Австрії було застосовано Інтернет-голосування під час виборів до студентського об'єднання «Федерація студентів». Не дивлячись 
на те, що Австрія не дозволяє застосовувати онлайн-голосування під час парламентських виборів, законодавством не забороняється онлайнголосування під час виборів до студентських об’єднань Австрії.

У Фінляндії 2008 р. онлайн-голосування відбулося на місцевих виборах. Однак виборцям не дозволили голосувати з дому, а встановили кабіни для голосування 3 доступом до мережі Інтернет на виборчих дільницях. У підсумку ці вибори закінчилися тим, що через збій системи неможливо було порахувати частину голосів, i необхідно було повторно проводити вибори на тих виборчих дільницях, де застосовувалося онлайнголосування. В результаті, пілотне тестування у Фінляндії відмінили (ОПОРА, 2016).

У Швейцарії у 2003 р. вперше відбулося експериментальне електронне голосування через систему «EVoting». Згідно 3 планами швейцарського уряду, на чергових парламентських виборах у 2015 р. в мережі Інтернет могла вже проголосувати абсолютна більшість громадян, навіть ті, які перебували поза межами своєї країни (Шелудько, 2015, с. 77-78). Швейцарія постійно продовжує розширювати використання е-голосування. На сьогодні у Женеві близько 30\% місцевих виборців здійснює Інтернет-голосування. 3 метою удосконалення безпеки виборчого процесу було запроваджено процедуру електронного голосування 3 авторизацією за індивідуальним кодом (Кохалик, 2015, с. 171).

Таким же чином як у Фінляндії онлайн-голосування у тестовому режимі проводилося і у Франції на місцевих виборах 2001 року - через кабіни для голосування на виборчих дільницях. В 2009 році французьке Міністерство закордонних справ, для полегшення процедури голосування, дозволило онлайн-голосування громадянам Франції, які проживають за кордоном (ОПОРА, 2016).

У Великобританії з 2002 по 2007 роки було проведено більше тридцяти тестових онлайн-голосуваннь на місцевих виборах. Проте у 2005 р. дійшли 
висновку, що системи е-голосування надто дорогі та не сприяють збільшенню участі у виборах (ОПОРА, 2016).

Неоднозначною також була реакція на запровадження е-голосування в низці країн світу.

Зокрема, Нідерланди у 2008 р. повернулись до паперового голосування, основними причинами були небезпека таємності голосу та велика залежність від продавців та сертифікованих агентств. Німеччина в 2009 р. процедуру еголосування проголосила неконституційною через брак публічності. На відміну від Норвегії, яка у 2014 р. тимчасово призупинила процес упровадження е-голосування у контексті проблеми безпеки (Кохалик, 2015, c. 171).

Також систему е-голосування застосовували і в інших країнах, а саме у Австралії, Бельгії, Індії, Ірландії, Іспанії, Канаді, Португалії та ін.

Перші спроби закріпити на законодавчому рівні запровадження електронного голосування у нашій державі були зафіксовані ще в 2011-му році, коли у Верховній Раді був зареєстрований законопроект Про концепцію «Запровадження системи електронного голосування» (Ліга Закон, 2011).

На даний час в Україні використання електронного голосування знаходиться лише на стадії активного обговорення. Згідно 3 «Концепцією розвитку електронної демократії в Україні та плану заходів щодо иї реалізації» від 8 листопада 2017 р. схваленої Кабінетом Міністрів України, період між 2017 і 2018 рр. відведений для формування основ впровадження електронного виборчого процесу, електронного голосування, а також електронних плебісцитів та електронних референдумів, а до 2020 року має відбутися безпосереднє впровадження цієї системи (Начос, 2018, с. 59; Законодавство України, 2017). Державним агентством з питань електронного урядування України 19 лютого 2019 року для громадського обговорення було запропоновано проект розпорядження Кабінету Міністрів України «Про затвердження плану заходів щодо реалізації Концепції розвитку електронної 
демократії в Україні на 2019-2020 роки» (Державне агентство 3 питань електронного урядування України, 2019).

Однак перспектива впровадження системи е-голосування в Україні також виявляється сумнівною у найближчі роки. Оскільки процедура голосування потребує ідентифікації виборця за допомогою електронного паспорта, який сьогодні на етапі впровадження. Також недоліком такої системи є вразливість комп'ютерних систем до вірусів, хакерських атак та можливості маніпуляцій i стороннього втручання у результати волевиявлення (Начос, 2018, с. 60).

Так експерт 3 кібербезпеки С. Денисенко відзначив, що Україні не варто повністю переходити на е-голосування. Оскільки від нього відмовилися більшість провідних країн світу. Він зазначив, що «за кордоном використовують хіба що сканування паперового бюлетеня і відправку цієї інформації в електронному вигляді. Іншою проблемою, є користувачі, у яких взагалі немає доступу до Інтернету... це i віддалені регіони, це і люди похилого віку, які не знають що таке комп'ютер. Також, ще однією небезпекою, яку несе електронне голосування, є можливість інших держав перешкоджати виборчому процесу» (УНІАН, 2019).

Проте не дивлячись на низку зазначених недоліків, система еголосування у виборчому процесі має і низку переваг, серед яких, точніші результати та більш швидкий підрахунок голосів; запобігання зловживанням під час підрахунку результатів на виборчих дільницях шляхом зменшення втручання людей; можливість голосувати 3-за кордону; можливість голосування для хворих виборців та людей із обмеженими можливостями; зменшення чисельності зіпсованих виборчих бюлетенів, оскільки електронні виборчі системи можуть застерігати виборців щодо недійсних голосів; заощадження коштів шляхом економії часу працівників, зменшення витрат на виготовлення та розповсюдження виборчих бюлетенів, уникнення затрат на транспортування бюлетенів; зменшення інцидентів продажу голосів, 
унеможливлюючи голосування одного виборця в декількох виборчих округах (Константинівська, 2018, с. 164).

Традиційні виборчі системи покликані задовольняти принципам демократичних виборів і референдумів, а саме не допускати примусу або впливу на виборців, забезпечувати вільне волевиявлення і таємний характер голосування, гарантувати недоторканність результатів виборів. Важливо дотримати всі ці принципи і при введенні нових методів голосування. Більш того, система електронного голосування повинна бути розроблена таким чином, щоб забезпечувати надійність і безпеку процесу голосування.

Висновки i перспективи подальших досліджень. Сучасні інформаційно-комунікаційні технології змінили обличчя політичного життя багатьох країн світу і Україна як держава з високим науково-технічним та інтелектуальним потенціалом не повинна знаходитись осторонь у цьому процесі. Застосування нових інформаційних технологій змінює суспільний дискурс, інструменти мобілізації громадян та стає дієвим інструментом залучення громадян до прийняття рішень через впровадження механізмів «едемократії». Однією з важливих умов практичного втілення є використання сучасних інформаційних технологій у виборчому процесі, а саме електронного голосування, яке не дивлячись на недоліки та економічні труднощі набуває все більшого розповсюдження у світових демократіях.

Треба продовжувати наукові розвідки у даному напрямку, щодо подальшої можливості запровадження системи електронного голосування у нашій державі. Однак умовою для використання механізмів електронного голосування в Україні повинні стати гарантії безпечності його реалізації. Нашій державі необхідно прийняти відповідну нормативно-правову базу, забезпечити розгалужену електронну інфраструктуру, встановити сертифіковане програмне забезпечення, здійснити підготовку виборчих органів та організувати навчання громадян щодо використання нових технологій, що дозволить провести визнані демократичні вибори з високим рівнем громадської довіри до виборчого процесу. Проте треба пам’ятати, що 
електронне голосування треба використовувати паралельно 3 традиційним

волевиявленням, а не як єдиний безальтернативний механізм обрання влади.

\section{ЛIТЕРАТУРА}

1. Акімов, А.В., 2018. Електронна демократія як альтернативна форма управління в Україні. Вчені записки ТНУ імені В.І. Вернадського. Серія: Державне управління, 29(68), 3, c. 23-27.

2. Барікова, А.А. 2016. Електронна держава: нова ефективність урядування. Київ: Юрінком Інтер.

3. Готун, А.М., 2008. Використання нових інформаційних технологій у виборчому процесі: світовий досвід і практика застосування в Україні. Вісник КНУ імені Tараса Шевченка. Серія: Філософія. Політологія, 89-90, с. 51-55.

4. Державне агентство з питань електронного урядування України, 2019. Проект розпорядження Кабінету Міністрів України «Про затвердження плану заходів щзодо реалізаиії Конщепиії розвитку електронної демократії в Україні на 2019 - 2020 роки». [online] Доступно: https:/www.e.gov.ua/ua/npa/proekt-rozporyadzhennyakabinetu-ministriv-ukrayini-pro-zatverdzhennya-planu-zahodiv-shchodo-realizaciyi-

koncepciyi-rozvitku-elektronnoyi-demokratiyi-v-ukrayini-na-2019-2020-roki [Дата звернення 19 лютий 2019].

5. Законодавство України, 2017. Про схвалення Конщепції розвитку електронної демократії в Украӥні та плану заходів щьодо ї̈ реалізащії. [online] Доступно: https://zakon.rada.gov.ua/laws/show/797-2017-p [Дата звернення 21 січень 2019].

6. Константинівська, А., 2018. Електронне голосування як інструмент електронної участі громадян. Вісник Львівського університету. Серія: Філософськополітологічні студї, 20, с. 162-167.

7. Кохалик, Х., 2015. Світовий досвід впровадження електронної демократії: проблеми та досягнення. Ефективність держсвного управління, 42, с. 169-174.

8. Ліга Закон, 2011. Про Конщепиію «Запровадження системи електронного голосування в Україні». [online] Доступно: http://search.ligazakon.ua/1_doc2.nsf/link1/JF6OG00A.html [Дата звернення 21 січень 2019].

9. Малиновський, В.Я., Грицяк, Н.В. та Семенченко, А.І., 2017. Вступ до курсу. Концептуальні засади електронного урядування та електронної демократії. В: А.І. Семенченка та В.М. Дрешпака, ред. Електронне урядування та електронна демократія. Київ: ФОП Москаленко О. М.

10. Махначова, Н. М., 2018. Е-демократія як інструмент розвитку громадянського суспільства та ефективного партнерства в публічній сфері. Державне управління: удосконалення та розвиток, [online] 10. Доступно: http://www.dy.nayka.com.ua/?op=1\&z=1320 [Дата звернення: 21 січень 2019]. DOI: 10.32702/2307-2156-2018.10.23.

11. Начос, Р.Р., 2018. Електронне голосування в Україні: перспективи запровадження та світовий досвід. [online] Доступно: http://www.pap.in.ua/1_2018/14.pdf [Дата звернення 10 січень 2019].

12. ОПОРА, 2016. Онлайн-голосування: Реквієм за мрією. [online] (Останнє оновлення 2 червень 2016) Доступно: https://www.oporaua.org/article/vybory/42544-onlainholosuvannia-rekviiem-za-mriieiu [Дата звернення 12 січень 2019].

13. УНІАН, 2019. Експерт назвав основні недоліки електронного голосування на виборах. [online] (Останнє оновлення 28 січня 2019) Доступно: https://www.unian.ua/elections/10425030-ekspert-nazvav-osnovni-nedoliki-elektronnogogolosuvannya-na-viborah.html [Дата звернення 30 січень 2019]. 
14. Фоміна, С.В., 2014. Способи та форми голосування на виборах у зарубіжних країнах. Збірник наукових праць Харківського начіонального педагогічного університету імені Г.С. Сковороди. Серія: Право, 21, с. 112-120.

15. Шелудько, Г.І., 2015. Електронне голосування як різновид виборчих інформаційнокомунікативних технологій: зарубіжний та вітчизняний досвід. Recent Studies of Social Sciences. Section: Politics, c. 76-80.

16. ACE project, 2019. Электронное голосование. [online] (Останнє оновлення 2 січень 2019) Доступно: http://aceproject.org/ace-ru/focus/e-voting/about [Дата звернення 25 січень 2019].

\section{Інформація про автора}

Данько Юрій Анатолійович - кандидат політичних наук, викладач кафедри політології, соціології і культурології Харківського національного педагогічного університету імені Г.С. Сковороди; e-mail: yuriyd86@gmail.com; ORCID: http://orcid.org/0000-0003-3544-5328.

Білоцерківська Наталя Геннадіївна - кандидат педагогічних наук, доцент, доцент кафедри політології, соціології і культурології Харківського національного педагогічного університету імені Г.С. Сковороди; e-mail: nataliya_belotserovskaya@ukr.net.; ORCID: http://orcid.org/0000-0002-9418-268X.

Стаття надійшла до редакції: 02.01.2019 р. $\quad$ Прийнята до друку: 23.02.2019 p. 